удК 347.78

В. Н. Белоусов

Байкальский государственный университет, г. Иркутск, Российская Федерация

\title{
ИЗМЕНЕНИЕ И ПРЕКРАЩЕНИЕ ДОГОВОРА АВТОРСКОГО ЗАКАЗА
}

\begin{abstract}
АНнотАция. В статье определен круг основных проблем, связанных с изменением и прекращением договора авторского заказа. Исследованы основания прекращения обязательств, применимые для договора авторского заказа. Дана оценка соотношению понятий «прекращение договора» и «расторжение договора», а также «изменение договора» и "расторжение договора». Проведено отграничение изменения договора от новации. Проанализированы случаи изменения и расторжения договора по инициативе одной из сторон в судебном порядке. Рассмотрены правила об одностороннем отказе от исполнения договора. Подтверждена целесообразность нормы о предоставлении заказчику права на односторонний отказ от договора, в случае истечения льготного срока, либо после окончания срока, при условии, что заказчик утратил интерес к договору. В результате проведенного исследования внесены предложения по совершенствованию законодательства в данной сфере.

кЛючЕВЫЕ словА. Прекращение обязательств; расторжение; изменение; договор; заказчик; автор; договор авторского заказа.

ИНФОРМАЦИЯ О СТАТЬЕ. Дата поступления 10 марта 2017 г.; дата принятия к печати 28 марта 2017 г.; дата онлайн-размещения 15 июня 2017 г.
\end{abstract}

V. N. Belousov

Baikal State University, Irkutsk, Russian Federation

\section{CHANGE AND TERMINATION OF COMMISSIONING CONTRACT}

\begin{abstract}
The article determines the range of problems connected with change and termination of commissioning contract. It investigates the grounds of cancellation of obligations applied for the commissioning contract. It assesses the correlation of concepts "termination of contract» and "dissolution of contract», as well as "alteration of contract» and "dissolution of contract». It carries out the limitation of commissioning contract from innovation. It analyses cases of change and dissolution of contract by either party by judicial procedure. It examines the rules of contract repudiation. The article confirms the expediency of norms in granting the right contract repudiation either in case of grace period expiration or after the expiry of the time limit provided that the customer has lost interest in the case. As the result of the study undertaken, it offers proposals in improving legislation in this sphere. KEYWORDS. Termination of contract; dissolution; change; contract; customer; author; commissioning contract.
\end{abstract}

ARTICLE INFO. Received March 10, 2017; accepted March 28, 2017; available online June 15, 2017.

Заключение договора авторского заказа предполагает его надлежащее исполнение контрагентами. Так, обязанности автора по договору авторского заказа завершаются передачей заказчику созданного произведения науки, литературы, искусства, соответствующего соглашению сторон. Однако в некоторых случаях может возникнуть необходимость в досрочном прекращении или изменении анализируемого договора. В этой связи нельзя не отметить, что в гражданском законодательстве не предусмотрено специальных норм об изменении или прекращении договора авторского заказа. Исключение составляет лишь регламентированная

\section{Baikal Research Journal}


законодателем возможность заказчика в отдельных случаях в одностороннем порядке отказаться от данного договора. Поэтому при необходимости изменения или прекращения договора авторского заказа сторонам необходимо руководствоваться положениями гл. 26 ГК РФ - прекращение обязательств, а также следует учитывать нормы гл. 29 ГК РФ - изменение и расторжение договоров.

Примечательно, что ст. 407 ГК РФ называется «Основания прекращения обязательств», однако в данной статье не содержится конкретных оснований, а указывается, что обязательство прекращается полностью или частично по основаниям, предусмотренным ГК РФ, другими законами, иными правовыми актами или договором. Прекращение обязательства по требованию одной из сторон допускается только в случаях, предусмотренных договором или законом. С 1 июня 2015 г. Федеральным законом «О внесении изменений в часть первую Гражданского кодекса Российской Федерации» ${ }^{1}$ ст. 407 ГК РФ дополнена п. 3 следующего содержания: «Стороны своим соглашением вправе прекратить обязательство, а также определить последствия его прекращения, если иное не предусмотрено законом или не вытекает из существа обязательства». Несомненно, что включение данного правила призвано обеспечить еще большую диспозитивность норм обязательственного права, но в то же время следует согласиться с В. В. Кулаковым, что данный пункт ничего нового в ГК РФ не добавляет, поскольку и в прежней редакции ГК РФ не запрещал заключение подобных соглашений [1, с. 87]. Конкретные основания прекращения обязательств называются и раскрываются в ст. 408-419 ГК РФ. Обратимся к анализу оснований прекращения обязательства с учетом специфики договора авторского заказа.

Нетипичными, а в некоторых случаях и неприменимыми для договора авторского заказа являются такие основания для прекращения обязательств, как зачет, прощение долга, новация, отступное, прекращение обязательства совпадением должника и кредитора в одном лице. В подтверждение этого вывода следует отметить, что в судебной практике не встречаются случаи прекращения договора авторского заказа по данным основаниям.

Помимо указанных выше оснований, обязательство прекращается невозможностью его исполнения, если она вызвана обстоятельством, за которые ни один из контрагентов не отвечает (ст. 416 ГК РФ). В юридической литературе обосновано мнение о том, что невозможность исполнения означает объективную неосуществимость действий, предусмотренных условиями обязательства, а не невозможностью действий соответствующим лицом [2, с. 17]. О. М. Надточий разделяя указанный подход, отмечает, что невозможность исполнения обязательства существует как явление материального мира, которое независимо от сознания субъектов обязательственного правоотношения [3, с. 107].

Из изложенного следует, что невозможность исполнения наступает помимо воли контрагентов, носит объективный характер. Вместе с тем в науке гражданского права дискуссионным является вопрос о том, прекращается ли обязательство невозможностью исполнения по обстоятельствам, за которые несет ответственность одна из сторон.

Высказано мнение о том, что если обязательство невозможно исполнить ввиду виновных действий контрагента, то следует констатировать прекращение обязанности исполнения в натуре, но не прекращение всех прав и сторон субъектов обязательства. Так, виновную сторону, возможно, привлечь к гражданско-правовой ответственности. Иными словами ученые полагают, что обязанность исполнения

${ }^{1}$ О внесении изменений в часть первую Гражданского кодекса Российской Федерации : федер. закон от 8 марта 2015 г. № 42-ФЗ // Собрание законодательства РФ. 2015. № 10. Ст. 1412.

\section{Baikal Research Journal}

электронный научный журнал Байкальского государственного университета 
обязательства виновной стороной трансформируется в обязанность возместить причиненные убытки $\left[4\right.$, с. 24]. Данный подход отражен и в судебной практике ${ }^{2}$.

Вместе с тем в доктрине предлагается и противоположный вывод. В соответствии с данной позицией обязательство прекращается в силу объективной невозможности исполнения, независимо от того, несут ли стороны ответственность за ее наступление [5, с. 486]. В случае привлечения к гражданско-правовой ответственности возникает новое охранительное правоотношение [6, с. 10-11]. Данный вывод представляется более убедительным. О. М. Надточий справедливо отмечает, что при замене объекта обязательства происходит прекращение прежнего обязательства с одновременным возникновением нового. Это объясняется тем, что один объект правоотношения, заключавшийся в совершении действий, которые направлены на реальное исполнение прекращается. Однако одновременно появляется другой объект, состоящий из действий, которые направлены на реализацию мер ответственности. Поэтому неоправданно говорить об изменении правоотношения. Объект имеет определяющее значение для обязательства, поскольку от него зависит совокупность прав и обязанностей, которые и будет составлять содержание обязательства [3, с. 109].

В зависимости от обстоятельств, повлекших невозможность исполнения обязательства, в доктрине гражданского права принято выделять фактическую и юридическую невозможность исполнения [7, с. 51]. В качестве фактической невозможности понимается физическое отсутствие у обязанного субъекта возможности исполнить обязательство. Например, невозможность исполнения автором своей обязанности по передаче заказчику фотографий после проведенной фотосессии в связи со случайной гибелью фотоаппарата, на котором хранились снимки. Особенность юридической невозможности исполнения обязательства состоит в том, что препятствием для исполнения обязательства, служит издание акта органа государственной власти или органа местного самоуправления (ст. 417 ГК РФ). Например, отчуждение недвижимого имущества в связи с изъятием земельного участка для государственных нужд делает невозможным исполнение обязательства, по которому автор обязался осуществить в доме заказчика роспись стен по мотивам русских сказок.

Для прекращения обязательства в связи с невозможностью исполнения, необходимо, чтобы соответствующее обстоятельство появилось в период действия обязательства, а не в момент его возникновения. Эти обстоятельства не будут являться основанием для прекращения договора. В Принципах международных коммерческих договоров (принципах УНИДРУА) закреплено правило о том, что если стороны знали в момент заключения договора о невозможности исполнения, то это не влияет на действительность договора ${ }^{3}$.

Рассматривая такое основание для прекращения обязательства как смерть гражданина, следует отметить, что обязательство прекращается, если оно не может быть изменено без личного участия должника, либо обязательство другим образом неразрывно связано с личностью должника (п. 1 ст. 418 ГК РФ). Договор авторского заказа следует отнести к числу фидуциарных сделок, поскольку во многих случаях решающее значение для заключения договора авторского заказа имеют личные качества автора, его репутация. Поэтому смерть автора является безусловным основанием для прекращения данного договора. В то же время смерть заказчика влечет прекращение договора авторского заказа, только в слу-

${ }^{2}$ Информационное письмо Президиума ВАС РФ от 21 дек. 2005 г. № 104 // Вестник ВАС РФ. 2006. № 4 .

${ }^{3}$ Принципы международных коммерческих договоров (Принципы УНИДРУА) 1994 г. // Библиотечка Российской газеты. 2001. Вып. 13.

\section{Baikal Research Journal}

электронный научный журнал Байкальского государственного университета 
чае если исполнение предназначено лично для него, либо обязательство другим образом неразрывно связано с личностью заказчика (п. 2 ст. 418 ГК РФ). Кроме того, договор авторского заказа может быть прекращен в связи с ликвидацией юридического лица, выступающего заказчиком в данном договоре.

Анализируя нормы об изменении и расторжении договора, следует руководствоваться ст. 450 ГК РФ, согласно которой, договор изменяется или расторгается по соглашению сторон, а в установленных законом случаях по требованию одной из сторон. Однако А. Ю. Кабалкин полагает: «...вряд ли можно согласиться, что ГК РФ последовательно исходит из принципа неизменности договора» [8, с. 22]. Необходимо обратить внимание на то, что некоторые ученые предлагают исходить из принципа «святости договора» [9, с. 92], принципа неизменности и нерасторжимости договора $[10$, с. 283]. А. С. Егорова в этой связи предлагает включить в ГК РФ норму, в соответствии с которой, договор, заключенный должным образом, является обязательным для исполнения сторонами [9, с. 92].

Действительно, в гражданском в гражданском законодательстве содержится достаточно оснований для досрочного прекращения или изменения договора. Поэтому считаем обоснованной позицию о том, что в настоящее время уместнее говорить о принципе стабильности гражданского оборота [11, с. 70].

Рассматривая вопрос о соотношении понятий «прекращение договора» и "расторжение договора» необходимо заметить следующее. При расторжении договора обязательства контрагентов прекращаются (п. 2 ст. 453 ГК РФ). Аналогичный подход закреплен и в юридической литературе. 3. М. Заменгоф отмечала, что в случае расторжения договора прекращается его действие [12, с. 20]. Вместе с тем прекращение договора не во всех случаях представляет собой расторжение договора (например, прекращения договора в связи с невозможностью исполнения). В этой связи под прекращением договора в теории права предлагают понимать правовой результат в виде отмены действия договора и возникших на его основе прав и обязанностей контрагентов, порождаемый юридическими фактами, которые имеют как волевой, так и неволевой характер [13, с. 5]. Расторжение договора всегда отличает специальная направленность воли на его прекращение. Следовательно, расторжение договора - это волевое действие, целью которого является прекращение действия договора [14, с. 11]. Таким образом, понятия «прекращение договора» и «расторжение договора» соотносятся между собой как часть и целое, где частным случаем прекращения договора является его расторжение (исключительно при наличии воли контрагента).

Следует также различать понятия «изменение договора» и «расторжение договора».

Расторжение договора влечет прекращение неисполненных договорных обязательств. 3. М. Заменгоф в свою очередь указывала, что расторжение договора направлено на досрочное прекращение действия договора на будущее время. Однако права и обязанности, вытекающие из обязательств, принятых на себя контрагентами на период, который предшествовал расторжению договора, сохраняются полностью [12, с. 22-23]. Данный вывод отражен и в судебной практике. Так, Высший Арбитражный суд неоднократно отмечал, что при расторжении договора прекращается обязанность должника совершать в будущем действия, которые являются предметом договора. Поэтому неустойка, предусмотренная за неисполнение или ненадлежащего исполнение обязанности, начисляется до даты расторжения договора. Вместе с тем условия договора, которые предполагают их применение и после расторжения договора (например, гарантийные обязательства в отношении товаров или работ по расторгнутому впоследствии договору), или имеют целью регулирование отношений сторон в период после расторжения (на-

\section{Baikal Research Journal}


пример, о порядке возврата уплаченного аванса и т. п.), сохраняют свое действие и после расторжения договора. Однако данные правила носят диспозитивный характер, следовательно, иное может быть установлено соглашением сторон ${ }^{4}$.

В теории гражданского права встречается предложение о выделении двух моделей расторжения договора в ситуации, когда должник в нарушение договора исполнил свое обязательство лишь частично. В соответствии с первой моделью (пропорциональное расторжение) управомоченный субъект (кредитор) инициирует расторжение договора только в части того, что осталось не исполненным. В рамках второй модели (непропорциональное расторжение) кредитор отказывается от договора в целом [15, с. 38-39]. Следует отметить, что встречаются и критические замечания на данное предложение. Отказ от исполнения договора в части непредоставленного исполнения учеными рассматривается как изменение, а не как расторжение договора. Данный вывод представляется наиболее убедительным. В п. 2 ст. 450.1 ГК РФ указывается, что в случае одностороннего отказа от договора полностью или частично, если такой отказ допускается, договор считается расторгнутым или измененным. Следовательно, частичный отказ является разновидностью изменения договора. По этой причине существование «пропорционального расторжения договора», как справедливо отмечают указанные авторы, невозможно по российскому гражданскому праву [16, с. 67].

Изменение условий договора имеет своим результатом не полное прекращение правовой связи между его контрагентами, а лишь изменение содержания договорных обязательств, дополнение его новыми правами и обязанностями [12, с. 23]. М. И. Брагинский, В. В. Витрянский в свою очередь отметили, что при изменении договора изменяются условия договора, но не его модель [17]. В случае изменения модели договора необходимо говорить о новации. Особенность новации заключается в том, что новый договор создается на основе первоначального, правовая связь контрагентов в этом случае не прекращается [11, с. 72]. Так, например, не является новацией изменение срока или цены договора. В то же время в случае замены предмета договора авторского заказа следует говорить о новации, а не изменении данного договора.

Изменение и расторжение гражданско-правового договора возможно по соглашению сторон, если иное не предусмотрено законом или договором. В литературе указывается, что наделение контрагентов широкой возможностью определять судьбу договора является одним из прямых выражений договорной свободы (принципа свободы договора). Те, кто обладают правом заключать договор, должны быть свободны и в вопросах его расторжения [17]. При этом суды указывают, что изменение или расторжение договора допускается в отношении договора, являющегося действительным ${ }^{5}$.

Соглашение об изменении или о расторжении договора совершается в той же форме, что и договор (п. 1 ст. 452 ГК РФ). Вместе с тем при определенных обстоятельствах соглашение о расторжении договора может быть изначально заложено в текст основного договора. Например, стороны в договоре вправе предусмотреть условие о том, что в случае, если один из контрагентов в пользу другого не производит исполнение, договор «автоматически» расторгается без направления уведомления об этом [18]. В частности, в договоре авторского заказа стороны могут предусмотреть условие, по которому невыплата вознаграждения автору будет являться «автоматическим» основанием для расторжения договора. При этом

${ }^{4}$ О последствиях расторжения договора : постановление Пленума Высш. Арбитр. Суда РФ от 6 июня 2014 г. № 35 // Вестник ВАС РФ. 2014. № 8 ; Информационное письмо от 21 дек. 2005 г. № 104.

${ }^{5}$ Определение Верховного Суда РФ от 25 июня 2013 г. № 18-КГ13-42 [Электронный ресурс] // СПС «Консуль-тант Плюс» .

\section{Baikal Research Journal}

электронный научный журнал Байкальского государственного университета 
кредитор не должен принимать исполнение по истечении предусмотренного срока исполнения, т.к. в ином случае его действия могут расцениваться как согласие на изменение первоначальных условий соглашения [18].

Помимо изменения и расторжения договора по соглашению сторон в гражданском законодательстве предусмотрена возможность его изменения и расторжения по инициативе одной стороны (в судебном и во внесудебном порядке). К. С. Безик справедливо отмечает, что право на одностороннее изменение или расторжение договора во внесудебном порядке может быть, либо охранительным, либо регулятивным. В то время как право на одностороннее изменение или расторжение договора в судебном порядке является исключительно охранительным [19, с. 6].

В частности, по требованию одной из сторон договор может быть изменен или расторгнут по решению суда в случае существенного нарушения договора другой стороной. При этом уточняется, что существенным признается нарушение договора одним из контрагентов, которое влечет для другого контрагента такой ущерб, что он в значительной степени лишается того, на что был вправе рассчитывать при заключении договора (п. 2 ст. 450 ГК РФ).

Основанием для расторжения договора может послужить нарушение установленных в договоре цены или сроков. Однако факт нарушения не может являться основанием для расторжения договора, должна быть доказана существенность нарушения [20]. В литературе указывается, что решающее значение имеет не размер ущерба, а его соотношение с тем, чего мог ожидать от исполнения контрагент [17]. Нарушение договора признается существенным, если в результате такого нарушения у другой стороны образуется чистый убыток от договора. Более того существенное нарушение договора может выражаться в невозможности для другой стороны достигнуть определенного результата [16, с. 128]. Схожий вывод содержится и в судебных решениях ${ }^{6}$.

Помимо существенного нарушения условий договора, основанием для изменения или расторжения договора в судебном порядке, является существенное изменение обстоятельств, из которых стороны исходили при заключении договора. В данной ситуации речь идет о крайней затруднительности исполнения договора. Иными словами исполнить договор при таких условиях возможно, но это приведет к таким последствиям для контрагента, что теряется смысл вступления в данные отношения [11, с. 78].

Из анализа ст. 451 ГК РФ следует, что для расторжения договора в связи с существенным изменением обстоятельств необходимо наличие в совокупности следующих условий о том, что в момент заключения договора данные обстоятельства были: 1) заранее непредвиденными; 2) непреодолимыми; 3) исполнение договора без изменений его условий повлекло бы для контрагента такой ущерб, что он в значительной степени лишался того, на что мог рассчитывать при заключении договора, т. е. чрезмерными; 4) из существа договора не следует, что риск изменения обстоятельств несет заинтересованная сторона [11, с. 79-80]. В этой связи Т. Г. Очхаев справедливо утверждает, что удовлетворение судом анализируемых требований возможно при наличии фактов, свидетельствующих о существенности, исключительности, непредвиденности возникших обстоятельств [21].

Вместе с тем нельзя не отметить, что суды крайне редко признают обоснованность и правомерность изменения или расторжения договора в связи с существенным изменением обстоятельств. Так, факты неисполнения обязательств сторонами, изменения курсов валют не признаются основаниями для изменения

${ }_{6}^{6}$ Постановление ФАС Северо-Кавказского округа от 18 дек. 2006 г. по делу № Ф32-68255/200550/1092 [Элек-тронный ресурс] // СПС «Консультант Плюс».

\section{Baikal Research Journal}

электронный научный журнал Байкальского государственного университета 
или прекращения договора [22]. Кроме того, суды не признают существенным изменением обстоятельств финансовый кризис ${ }^{7}$, резкое ухудшение финансового состояния стороны договора, сокращение штата, поскольку вступая в договорные отношения, стороны могли учесть экономическую ситуацию, спрогнозировать ухудшение своего финансового положения ${ }^{8}$ На сегодняшний день отсутствуют примеры из судебной практики, в которых договор авторского заказа прекращался бы в связи с существенным изменением обстоятельств.

С 1 июня 2015 г. в ГК РФ введена отдельная статья, посвященная такому внесудебному порядку прекращения договора, как отказ от договора (исполнения договора) (ст. 450.1 ГК РФ). Нельзя не согласиться с М. А. Егоровой в том, что отказ от договора не является формой гражданско-правовой ответственности. Действия по одностороннему отказу от исполнения договора не направлены на причинение другой стороне договора имущественных лишений [23, с. 7].

В соответствии с п. 1 ст. 450.1 ГК РФ предоставленное законом или договором право на односторонний отказ от договора может быть осуществлено контрагентом путем уведомления другого контрагента об отказе от договора. По общему правилу договор прекращается с момента получения данного уведомления. При этом в решениях судах разъясняется, договор не считается расторгнутым, если после уведомления контрагента о расторжении подписано дополнительное соглашение с указанием на неизменность условий договора. Исполнение данного договора продолжается ${ }^{9}$

Однако из процитированной нормы закона неясно, в какой форме должно быть уведомление об отказе от договора. Ранее нами уже обращалось внимание на п. 1 ст. 452 ГК РФ, в соответствии с которым соглашение об изменении или о расторжении договора совершается в той же форме, что и договор. В доктрине гражданского права высказано мнение о том, что правило п. 1 ст. 452 ГК РФ должно применяться по аналогии и для отказа от договора. Свой вывод ученые обосновывают тем, что односторонний отказ, как и соглашение сторон о расторжении или изменении договора, представляет собой сделку, поэтому отказ от договора должен совершаться в той же форме, что и договор [24, с. 672]. Данный вывод представляется убедительным, хотя для устранения необходимости применять аналогию закона, целесообразно в п. 1 ст. 450.1 ГК РФ закрепить правило о форме уведомления об одностороннем отказе от договора.

В случае осуществления контрагентом права на одностороннее изменение условий договора или при одностороннем отказе от его исполнения контрагент должен действовать добросовестно и разумно, учитывая права другой стороны. Нарушение этой обязанности может повлечь отказ в судебной защите полностью или частично, в том числе признание ничтожным одностороннего изменения условий обязательства или одностороннего отказа от его исполнения ${ }^{10}$.

В п. 5 ст. 450.1 ГК РФ указывается, что в случаях, если при наличии оснований для отказа от договора контрагент, имеющий право на такой отказ, подтверждает действие договора, отказ по тем же основаниям не допускается. В юридической ли-

${ }^{7}$ Определение ВАС РФ от 27 апреля 2010 г. № 2912/10 по делу № А60-10229/2009-С1 [Электронный ресурс] // СПС «Консультант Плюс» ; Постановление ФАС Восточно-Сибирского округа от 19 января 2006 г. № Ф33-23686/04-С1-Ф02-6957/05-С2 [Электронный ресурс] // Там же.

${ }^{8}$ Постановление Президиума ВАС РФ от 30 ноября 2010 г. № 9600/10 по делу № A17-1960/2009 // Вестник ВАС РФ. 2011. № 3.

${ }^{9}$ Определение Верховного Суда РФ от 2 июля 2015 г. № 305-ЭС15-2415 по делу № A40-28123/2014 [Электронный ресурс] // СПС «Консультант Плюс».

${ }^{10} \mathrm{O}$ некоторых вопросах применения общих положений Гражданского кодекса Российской Федерации об обязательствах и их исполнении : постановление Пленума Верхов. Суда РФ от 22 нояб. 2016 г. № 54 // Бюллетень Верховного суда. 2017. № 1.

\section{Baikal Research Journal}

электронный научный журнал Байкальского государственного университета 
тературе критически оценивают введение данной нормы в ГК РФ. Так, К. С. Безик справедливо отмечает, что указанная норма будет вызывать трудности в процессе ее применения. Это объясняется тем, что в ГК РФ введен новый термин «подтверждение действия договора». Однако раскрывается только один частный случай подтверждения, а именно - принятие от другой стороны предложенного последней исполнения обязательства. Неясно, какие еще случаи будет охватывать это понятие. Не будет ли телефонный разговор являться подтверждением действия договоpa? Кроме того, понятие «принятие исполнения» также не получило однозначного определения в теории гражданского права [16, с. 192-193].

В гражданском законодательстве правила об одностороннем отказе от договора авторского заказа предусмотрены только для заказчика. Так, в соответствии со ст. 1289 ГК РФ по истечении льготного срока, предоставленного автору, заказчик вправе отказаться в одностороннем порядке от договора авторского заказа. Учитывая, что такой отказ является правомерным действием, то и нет оснований для применения правил об ответственности. Кроме того, заказчик вправе отказаться от договора авторского заказа непосредственно по окончании срока, установленного договором для его исполнения, если договор к этому времени не исполнен, а из его условий явно вытекает, что при нарушении срока исполнения договора заказчик утрачивает интерес к договору.

Несмотря на то, что одной из основных причин для закрепления особых правил о договоре авторского заказа является усиленная защита «слабой стороны», т. е. автора, норма о предоставлении заказчику права на односторонний отказ от договора является оправданной. Это объясняется тем, что в практике возникает немало ситуаций, когда произведение создается с нарушением указанного в договоре срока, а заказчик уже утратил интерес к созданному произведению. Например, стороны заключили договор авторского заказа, согласно которому автор обязался создать стихотворение, которое заказчик планировал зачитать на свадьбе своего родственника. В литературе приводятся и другие примеры, правомерного отказа от исполнения договора авторского заказа в случае утраты интереса: невозможность использования произведения в силу его относимости к определенному событию - сценарий проведения открытия олимпийских игр, если к моменту его написания они уже начались; научно-практический комментарий к утратившему силу законодательству [25, с. 137].

Изменение и прекращение договора влечет наступление последствий, закрепленных в ст. 453 ГК РФ. С 1 июня 2015 г. введена норма, посвященная возмещению убытков при прекращении договора (ст. 393.1 ГК РФ). Следует отметить, что порядок исчисления убытков при расторжении договора, закрепленный в ст. 393.1 ГК РФ аналогичен правилам исчисления убытков, предусмотренным для договора поставки (ст. 524 ГК РФ). Кроме того, с 1 июня 2015 г. появилась возможность применять к отношениям сторон измененного или расторгнутого договора положения об обязательствах из неосновательного обогащения. Последствия расторжения договора, отличные от предусмотренных законом, могут быть установлены в соглашении сторон с соблюдением ограничений свободы договора, установленных в постановлении Пленума ВАС РФ «О свободе договора и ее пределах» ${ }^{11}$. Например, в договоре может быть предусмотрено такое последствие как возврат исполненного по договору до момента его расторжения. Однако такое последствие вряд ли применимо для договора авторского заказа.

Таким образом, в случае прекращения договора авторского заказа следует применять общие нормы о прекращении обязательств, а также правила об изме-

${ }^{11}$ О свободе договора и ее пределах : постановление Пленума ВАС РФ от 14 марта 2014 г. № 16 // Вестник ВАС РФ. 2014. № 5 .

\section{Baikal Research Journal}

электронный научный журнал Байкальского государственного университета 
нении и расторжении гражданско-правового договора с учетом специфики договора авторского заказа. В случае нарушения автором срока договора авторского заказа у заказчика возникает право на односторонний отказ от договора.

\section{Список использованной литературы}

1. Кулаков В. В. Актуальные вопросы прекращения обязательств / В. В. Кулаков // Ученые труды Российской академии адвокатуры и нотариата. - 2015. — № 3 (38). C. 87-92.

2. Свит Ю. П. Прекращение договора вследствие невозможности исполнения / Ю. П. Свит // Законы России: опыт, анализ, практика. - 2008. - № 2. - С. 17-23.

3. Надточий О. М. Место невозможности исполнения обязательства в системе гражданско-правовых фактов / О. М. Надточий // Известия Иркутской государственной экономической академии. - 2013. - № 2 (88). - С. 107-110.

4. Шумейко И. Ю. Проблемы исполнения обязательств в гражданском праве : автореф. дис. ... канд. юрид. наук : 12.00.03 / И. Ю. Шумейко. - Ростов н/Д., 2009. - 30 с.

5. Карапетов А. Г. Расторжение нарушенного договора в российском и зарубежном праве / А. Г. Карапетов. - М. : Статут, 2007. - 876 с.

6. Кархалев Д. Н. Соотношение мер защиты и мер ответственности в гражданском праве России : дис. ... канд. юрид. наук : 12.00.03 / Д. Н. Кархалев. - Екатеринбург, 2003. - $180 \mathrm{c.}$

7. Эрделевский А. М. Прекращение обязательств невозможностью исполнения / А. М. Эрделевский // Законы России. - 2007. - № 8. - С. 51-54.

8. Кабалкин А. Ю. Изменение и расторжение договора / А. Ю. Кабалкин // Российская юстиция. - 1996. - № 10. - С. 22 .

9. Егорова А. С. Система правовых средств, обеспечивающих стабильность гражданско-правового договора / А. С. Егорова // Вестник Московского университета МВД России. - 2010. - № 9. - С. 90-94.

10. Гражданское право России. Курс лекций / М. И. Брагинский, В. В. Залесский, Н. И. Клейн, В. Н. Литовкин [и др.] ; под ред. О. Н. Садикова. - М. : Юрид. лит., 1996. Ч. $1 .-304$ c.

11. Гражданское право: общие положения о договорах : учеб. пособие для бакалавров / отв. ред. В. В. Долинская, В. Л. Слесарев. - М. : Проспект, 2016. - 96 с.

12. Заменгоф 3. М. Изменение и расторжение хозяйственных договоров / З. М. Заменгоф. - М. : Юрид. лит., 1967. - 144 с.

13. Архипова О. А. О соотношении правовых понятий «прекращение договора» и «расторжение договора» в гражданском и трудовом праве / О. А. Архипова, Т. Ю. Лузянин // Правовые проблемы российской государственности / под ред. В. М. Лебедева [и др.]. Томск : Изд-во Нац. исслед. Том. гос. ун-та, 2014. - С. 5-8.

14. Соменков С. А. Прекращение и расторжение договоров: общее и особенное / С. А. Соменков // Законы России: опыт, анализ, практика. - 2008. - № 2. - С. 3-16.

15. Карапетов А. Г. Основные тенденции правового регулирования расторжения нарушенного договора в зарубежном и российском гражданском праве : автореф. дис. ... д-ра юрид. наук : 12.00 .03 / А. Г. Карапетов. - М., 2011. - 46 с.

16. Безик К. С. Одностороннее изменение и расторжение договоров в гражданском праве Российской Федерации : монография / К. С. Безик. - Иркутск : Иркут. гос. ун-т, 2012. - 220 c.

17. Брагинский М. И. Договорное право. Общие положения / М. И. Брагинский, В. В. Витрянский. - М. : Статут, 2003. - Кн. 1. - 848 с.

18. Бычков А. Соглашение о расторжении договора / А. Бычков // ЭЖ Юрист. 2016. - № 12 .

19. Безик К. С. Одностороннее изменение и расторжение договоров в гражданском праве Российской Федерации : автореф. дис. ... канд. юрид. наук : 12.00 .03 / К. С. Безик. Иркутск, 2011. - 26 с.

20. Гражданский кодекс Российской Федерации: постатейный комментарий к разделу III «Общая часть обязательственного права» / А. В. Барков, А. В. Габов, М. Н. Илюшина [и др.] ; под ред. Л. В. Санниковой. - М. : Статут, 2016. — 622 с.

\section{Baikal Research Journal}


21. Очхаев Т. Г. Изменение и расторжение договора в связи с существенным изменением обстоятельств в правоприменительной практике / Т. Г. Очхаев // Вестник гражданского права. - 2011. - № 2. - С. 153-170.

22. Бабенко А. Иски об изменении и расторжении договоров в связи с финансовым кризисом / А. Бабенко // Корпоративный юрист. - 2009. - № 11. - С. 22-24.

23. Егорова М. А. Односторонний отказ от исполнения договора по законодательству Российской Федерации : автореф. дис. ... канд. юрид. наук : 12.00.03 / М. А. Егорова. M., 2006. -29 c.

24. Гражданское право : учебник / отв. ред. В. П. Мозолин. - М. : Проспект, 2012. T. 1. $-816 \mathrm{c}$.

25. Комментарий к Гражданскому кодексу Российской Федерации (учебно-практический) к ч. 4 / под ред. С. А. Степанова. - 4-е изд. - М. : Проспект, 2015. - 456 с.

\section{References}

1. Kulakov V. V. Topical issues of termination of obligations. Uchenye trudy Rossiiskoi akademii advokatury $i$ notariata $=$ Scientific Works of the Russian Academy of Advocacy and Notary, 2015, no. 3 (38), pp. 87-92. (In Russian).

2. Svit Yu. P. Termination of contracts by impossibility of execution. Zakony Rossii: opyt, analiz, praktika = Law of Russia: Experience, Analysis, Practice, 2008, no. 2, pp. 17-23. (In Russian).

3. Nadtochiy O. M. Impossibility of obligations fulfillment in the system of civil law facts. Izvestiya Irkutskoi gosudarstvennoi ekonomicheskoi akademii = Bulletin of Irkutsk State Economics Academy, 2013, no. 2 (88), pp. 107-110. (In Russian).

4. Shumeiko I. Yu. Problemy ispolneniya obyazatel'stv $v$ grazhdanskom prave. Avtoref. Kand. Diss. [Problems of executing obligations in civil law. Cand. Diss. Thesis]. Rostov-onDon, 2009. $30 \mathrm{p}$.

5. Karapetov A. G. Rastorzhenie narushennogo dogovora $v$ ros-siiskom $i$ zarubezhnom prave [Dissolution of infringed contract in Russian and foreign laws]. Moscow, Statut Publ., 2007. $876 \mathrm{p}$.

6. Karkhalev D. N. Sootnoshenie mer zashchity $i$ mer otvetstvennosti $v$ grazhdanskom prave Rossii. Kand. Diss. [Correlation of protective measures and liabilities in Russia's Civil Law. Cand. Diss.]. Yekaterinburg, 2003. 180 p.

7. Erdelevsky A. M. Termination of obligations by impossibility of execution. Zakony Rossii: opyt, analiz, praktika = Law of Russia: Experience, Analysis, Practice, 2007, no. 8, pp. 51-54. (In Russian).

8. Kabalkin A. Yu. Change and dissolution of contracts. Rossiiskaya yustitsiya = Russian Justice, 1996, no. 10, pp. 22-23. (In Russian).

9. Egorova A. S. System of legal ways providing stability of the civil-legal contract. Vestnik Moskovskogo universiteta MVD Rossii = Bulletin of Moscow University of the Ministry of Internal Affairs of the Russian Federation, 2010, no. 9, pp. 90-94. (In Russian).

10. Braginsky M. I., ZalesskyV. V., Klein N. I., Litovkin V. N. et al.; Sadikov O. N. (ed.). Grazhdanskoe pravo Rossii. Kurs lektsii [Civil Law of Russia F course of Lectures]. Moscow, Yuridicheskaya literature Publ., 1996. Pr. 1. 304 p.

11. Dolinskaya V. V., Slesarev V. L. (eds). Grazhdanskoe pravo: obshchie polozheniya o dogovorakh [Civil Law: general statements on contracts]. Moscow, Prospekt Publ., 2016. 96 p.

12. Zamengof Z. M. Izmenenie i rastorzhenie khozyaistvennykh dogovorov [Change and dissolution of economic contracts]. Moscow, Yuridicheskaya literature Publ., 1967. 144 p.

13. Arkhipova O. A., Luzyanin T. Yu. On correlation of legal concepts «dissolution of contract» and "termination of contract» in Civil and Labor Laws In Lebedev V. M. (ed.). Pravovye problemy rossiiskoi gosudarstvennosti [Legal problems of Russian statehood]. National Research Tomsk State University Publ., 2014, pp. 5-8. (In Russian).

14. Somenkov S. A. Termination and dissolution of contracts: the general and the particular. Zakony Rossii: opyt, analiz, praktika = Law of Russia: Experience, Analysis, Practice, 2008, no. 2, pp. 3-16. (In Russian).

15. Karapetov A. G. Osnovnye tendentsii pravovogo reguliro-vaniya rastorzheniya narushennogo dogovora $v$ zarubezhnom $i$ rossiiskom grazhdanskom prave. Avtoref. Dokt. Diss. [Main

\section{Baikal Research Journal}


trends of legal regulating of dissolution of the infringed contract in foreign and Russian Civil Law. Doct. Diss. Thesis]. Moscow, 2011. 46 p.

16. Bezik K. S. Odnostoronnee izmenenie i rastorzhenie dogovorov v grazhdanskom prave Rossiiskoi Federatsii [Unilateral change and dissolution of contracts in the Civil Code of the Russian Federation]. Irkutsk State University Publ., 2012. 220 p.

17. Braginsky M. I., Vitryansky V. V. Dogovornoe parvo. Obshchie polozheniya [Contract law. General statements]. Moscow, Statut Publ., 2003. Vol. 1. 848 p.

18. Bychkov A. Agreement on contract dissolution. EJ-Jurist, 2016, no. 12. (In Russian).

19. Bezik K. S. Odnostoronnee izmenenie i rastorzhenie dogovorov v grazhdanskom prave Rossiiskoi Federatsii. Avtoref. Kand. Diss. [Unilateral change and dissolution of contracts in the Civil Code of the Russian Federation. Cand. Diss. Thesis]. Irkutsk, 2011. 26 p.

20. Barkov A. V., Gabov A. V., Ilyushina M. N. et al.; Sannikova L. V. (ed.). Grazhdanskii kodeks Rossiiskoi Federatsii: postateinyi kommentarii $k$ razdelu III «Obshchaya chast' obyazatel'stvennogo prava» [Civil Law of the Russian Federation: clause-by-clause comment on Article III «General Part of Obligatory Law»]. Moscow, Statut Publ., 2016. 622 p.

21. Ochkhayev T. G. Change and dissolution of contract in connection with substantial change of circumstances in law enforcement practice. Vestnik grazhdanskogo prava = Civil Law Review, 2011, no. 2, pp. 153-170. (In Russian).

22. Babenko A. Plaints of changes and dissolution of contracts in terms of financial crisis. Korporativnyi yurist $=$ Corporative Lawyer, 2009, no. 11, pp. 22-24. (In Russian).

23. Egorova M. A. Odnostoronnii otkaz ot ispolneniya dogovora po zakonodatel'stvu Rossiiskoi Federatsii. Avtoref. Kand. Diss. [Unilateral repudiation of obligations under contract under the law of the Russian Federation. Cand. Diss. Thesis]. Moscow, 2006. 29 p.

24. Mozolin V. P. (ed.). Grazhdanskoe pravo [Civil Law]. Moscow, Prospekt Publ., 2012. Vol. 1. $816 \mathrm{p}$.

25. Stepanov S. A. (ed.). Kommentarii $k$ Grazhdanskomu kodeksu Rossiiskoi Federatsii (uchebno-prakticheskii) $k$ ch. 4 [Comments on the Civil Code of the Russian Federation (learning and practical issues) to Part 4]. $4^{\text {th }}$ ed. Moscow, Prospekt Publ., 2015. 456 p.

\section{Информация об авторе}

Белоусов Владимир Николаевич - старший преподаватель, кафедра гражданского права и процесса, Байкальский государственный университет, 664003, г. Иркутск, ул. Ленина, 11, e-mail: vladimir89.89@inbox.ru.

\section{Author}

Vladimir N. Belousov - Senior Lecturer, Chair of Civil Law and Procedure, Baikal State University, 11 Lenin St., 664003, Irkutsk, Russian Federation; e-mail: vladimir89.89@inbox.ru.

\section{Библиографическое описание статьи}

Белоусов В. Н. Изменение и прекращение договора авторского заказа / В. Н. Белоусов // Baikal Research Journal. - 2017. — T. 8, № 2. - DOI: 10.17150/2411-6262.2017.8(2).5.

\section{Reference to article}

Belousov V. N. Change and termination of commissioning contract. Baikal Research Journal, 2017, vol. 8, no. 2. DOI: 10.17150/2411-6262.2017.8(2).5. (In Russian).

\section{Baikal Research Journal}

